\title{
A comparison of Eocene climate model results to quantified paleoclimatic interpretations
}

\author{
L. Cirbus Sloan ${ }^{\mathrm{a}}$ and Eric J. Barron ${ }^{\mathrm{b}}$ \\ ${ }^{a}$ Dept. of Geological Sciences, University of Michigan, Ann Arbor, MI 48109, USA \\ ${ }^{\mathrm{b}}$ Earth System Science Center and Dept. of Geological Sciences, Pennsylvania State University, University Park, PA \\ $16802, U S A$
}

(Received April 23, 1991; revised and accepted November 21, 1991)

\begin{abstract}
Sloan, L.C. and Barron, E.J. 1992. A comparison of Eocene climate model results to quantified paleoclimatic interpretations. Palaeogeogr., Palaeoclimatol., Palaeoecol., 93: 183-202.

The integration of climate model results and geologic information offers considerable potential for deriving greater insight into the geologic record. In this study, climate model results and quantified climatic interpretations derived from proxy data are compared, to assess model capabilities and to examine proxy data interpretations. Atmospheric general circulation model experiments were used to produce a range of "possible" representative Eocene climate states, based on current knowledge of the Eocene record. The climate model experiments incorporate two idealized endmembers of Eocene ocean-surface temperature distributions characterized by very different latitudinal gradients. Model results are compared to quantified interpretations of the climate of early Eocene North America in an attempt to identify one of the sea-surface temperature distributions as more likely to have existed during the Eocene.

The comparisons do not produce a conclusive match between inferred paleoclimatic information and any single case of model results, but some interesting insights become apparent. Model predictions of mean annual temperature and mean annual precipitation compare favorably to interpretations from geologic evidence, but there are large differences between model results and interpreted paleoclimatic parameters of minimum surface temperature and mean annual temperature range. Several possible causes for these differences are discussed.
\end{abstract}

\section{Introduction}

Paleoclimate investigations involving general circulation models (GCMs) have primarily focused on qualitative analyses of climate change rather than quantitative analyses. Qualitative analyses, in the form of sensitivity studies which involve model predictions of large-scale, first-order changes, have been most frequently used for two limiting reasons. First, paleoclimate modeling studies have been commonly structured as sensitivity studies because of limited spatial and temporal resolution of the models. For example, spatial resolution of the GCM at the National Center for Atmospheric

Correspondence to: L.C. Sloan, Department of Geological Sciences, University of Michigan, Ann Arbor, MI 48109, USA.
Research (the Community Climate Model (CCM)), is approximately $4.5^{\circ}$ in latitude by $7.5^{\circ}$ in longitude. Most other GCMs operate at similar resolution. This resolution is incapable of capturing many climatic processes which occur in smaller regions of time and space (e.g. mesoscale precipitation). Subgrid-scale processes are either parameterized or omitted entirely from the modeled climate system, limiting the accuracy of the predicted climate state. Additionally, model spatial resolutions like the one described here are too coarse for definition of regional climate interactions; this is important to consider in paleoclimate studies because proxy paleoclimate data no doubt reflect regional as well as global climate characteristics.

Restrictions created by temporal resolution of global climate models limit the character of practi- 
cal paleoclimate modeling studies in a similar manner. Geologic evidence can contain a climatic signal that generally reflects much higher or more varied temporal resolutions than the resolutions which global climate models typically produce. Climatic signals recorded by biotic and abiotic media may record a range of climatic behavior and timescales, from single events (e.g., floods), to annual or decadal conditions (e.g., of precipitation or drought) or longer. In contrast, climate model results represent average climate states for the imposed boundary and initial conditions, most commonly representing a monthly or yearly mean.

As the second limitation, paleoclimate modeling has often focused on qualitative studies because uncertainties also are associated with geologic information. Geologic data are critical for establishing boundary conditions and for evaluating modeled paleoclimatic results. Geologic interpretations are generally subject to increasing uncertainty with increasing age. Uncertainties associated with the data vary with the type of data and with the method of climatic interpretion. The implications for these uncertainties are discussed in detail below.

Because spatial and temporal resolution of models limits the accuracy of model-predicted climate for any single place and time, and because of uncertainties in boundary conditions, the broad scope of change between two or more cases of model results are generally focused on as the key issue in modeling studies. Comparison of model results to geologic information has most often been limited to broad scale and qualitative assessment for the same reasons.

Despite these limitations, qualitative studies have contributed greatly to understanding paleoclimate conditions and relationships, and there have been many instructive GCM paleoclimate sensitivity studies in the past two decades of climate modeling. Studies of note include investigations of the effects of mountains (e.g., Manabe and Terpstra, 1974; Kutzbach et al., 1989; Ruddiman and Kutzbach, 1989; Ruddiman et al., 1989; Manabe and Broccoli, 1990), effects of geographic configuration (e.g., Barron and Washington, 1984; Barron, 1985; Kutzbach and Gallimore, 1989), influence of sea surface temperatures (e.g., Schneider et al.,
1985; Sloan and Barron, 1990) and of ice sheets (e.g., Manabe and Broccoli, 1985; Kutzbach and Wright, 1985; Rind, 1987; Shinn and Barron, 1989) upon climate. These analyses have provided much insight into the processes of global climate change through geologic time. However, comparison of the quantitative results from paleoclimate experiments with geologic data has been largely unaddressed for the most part. Greater effort at modeldata intercomparison is a logical next step in paleoclimate research, in order to study the processes and mechanisms of global change at a more detailed level (e.g., Wing, 1991; Sloan and Barron, 1991).

In this pilot study, comparisons of quantified conditions are undertaken in an effort to relate model results and interpreted paleoclimatic conditions, and to examine model and data information in the same perspective. In the effort of relating model results to quantified paleoclimatic estimates, the discrepancies between conclusions from these two sources of information are explored.

Eocene climate model results are compared to quantitative paleoclimatic interpretations from faunal and floral data of early Eocene age. Eocene conditions are addressed for three reasons. First, Eocene climate is examined because the nature and character of the global, oceanic surfacetemperature gradient during this time is a subject of debate. Central to the debate are absolute values of tropical surface temperatures during the Eocene, and the character of the pole-to-equator sea surface temperature gradient at that time (e.g., Shackleton and Boersma, 1981; Matthews and Poore, 1980; Prentice and Matthews, 1988; Barron, 1987). Second, relatively abundant, quantified, paleoclimatic interpretations are available for the Eocene, primarily derived from paleobotanical data from western North America. Third, the early Eocene is thought to have been the warmest interval of the Paleogene (Barron, 1987; Wolfe, 1989; Rea et al., 1990). The cause of the climatic character of this time period is therefore of considerable interest.

Sea surface temperature (SST) values for the Paleogene, and especially for the early Eocene, are widely debated. Because of the interest in defining ocean surface temperature values during the 
Eocene, and the need to understand climatic processes related to paleoSSTs, evaluating model results produced from different SST conditions is a potentially useful task in many respects. Two major issues regarding SSTs have implications for understanding the Eocene Earth. The value of tropical sea surface temperatures is the first major issue; one that is important from a global climate point of view because tropical ocean surface temperatures in many respects drive the "heat engine" of the planet. Tropical SST values are also central to arguments and estimates of global ice volume at this time (e.g., Mathews and Poore, 1980; Barron, 1987). Additionally, temperature estimates for the tropical oceans have implications for biotic diversity records from low latitudes. There are discrepancies between isotopically-estimated sea surface temperature values and values inferred from marine biotic assemblages (e.g., Adams et al., 1990; Wei and Wise, 1990). The second major issue for Paleogene ocean surface temperatures is the character of the pole-to-equator sea surface temperature gradient. The steepness of the gradient as well as the actual temperature values of the gradient can influence the nature of the global climate, especially the intensity of the atmospheric circulation (Barron and Washington, 1982; Sloan, 1990). This is another instance where isotopic estimates of the meridional ocean surface temperature gradient during the Eocene (and during the Paleogene in general) are in conflict with estimates derived from marine biotic diversity records (Adams et al., 1990; Wei and Wise, 1990). The emphasis on continental climate in response to the specified SSTs in this paper presents a different way of addressing the SST question.

The remainder of this paper is divided into sections which provide a description of the climate model used, and the experiments carried out. These sections are followed by description of the paleoclimatic interpretations used to evaluate the model results, and comparison between model results and paleoclimatic evidence. Last is a discussion of the applied techniques, with conclusions regarding Eocene climate reconstructions and their comparison to proxy data, and implications for the general approach in paleoclimate modeling studies.

\section{Description of the climate model}

The model used for this study is a version of the Community Climate Model associated with the National Center for Atmospheric Research. The basic model version used here (CCM0) has been extensively documented by Pitcher et al. (1983). In the spatial domain the model has nine vertical levels representing the atmosphere to a height of approximately $28 \mathrm{~km}$. In the horizontal plane, model resolution is approximately $4.5^{\circ}$ latitude by $7.5^{\circ}$ longitude. The radiation-cloudiness scheme of Ramanathan et al. (1983) is included in the model; this revised radiation package produced climate model results more closely resembling present-day observations (Ramanathan et al., 1983). The interactive, continental hydrology subroutine of Washington and Williamson (1977) was also incorporated into the model.

Pitcher et al. (1983) demonstrate that model results compare favorably with observed climate parameters for both January and July conditions, but there is a weakness in the model performance that is relevant here. In some continental areas, the model produces summer surface temperatures that slightly exceed observed values (by $1-2^{\circ} \mathrm{C}$ ), and lower-than-observed winter temperatures (by up to $7^{\circ} \mathrm{C}$ ) (see Pitcher et al., 1983, fig. 7, p. 591). This is most likely due to the surface hydrology parameterization that was used (Pitcher et al., 1983). According to Kutzbach and Gallimore (1989), the temperature discrepancy places the $0^{\circ} \mathrm{C}$ isotherm about $5^{\circ}$ of latitude more equatorward over the continents than observed in winter. The discrepancy between observations and model results of present conditions may potentially hinder positive correlation between model results and proxy paleoclimate data, and will be considered in this analysis. The surface temperature bias also may affect the modeled annual temperature range in comparison to proxy data interpretations of this same quantity; this will also be considered below.

The model requires boundary conditions which describe land-sea distribution, distribution of surface temperatures at all ocean gridpoints, elevations of all land gridpoints, and latitudinal distribution of solar radiation. For all experiments, a land-sea distribution representing conditions at 


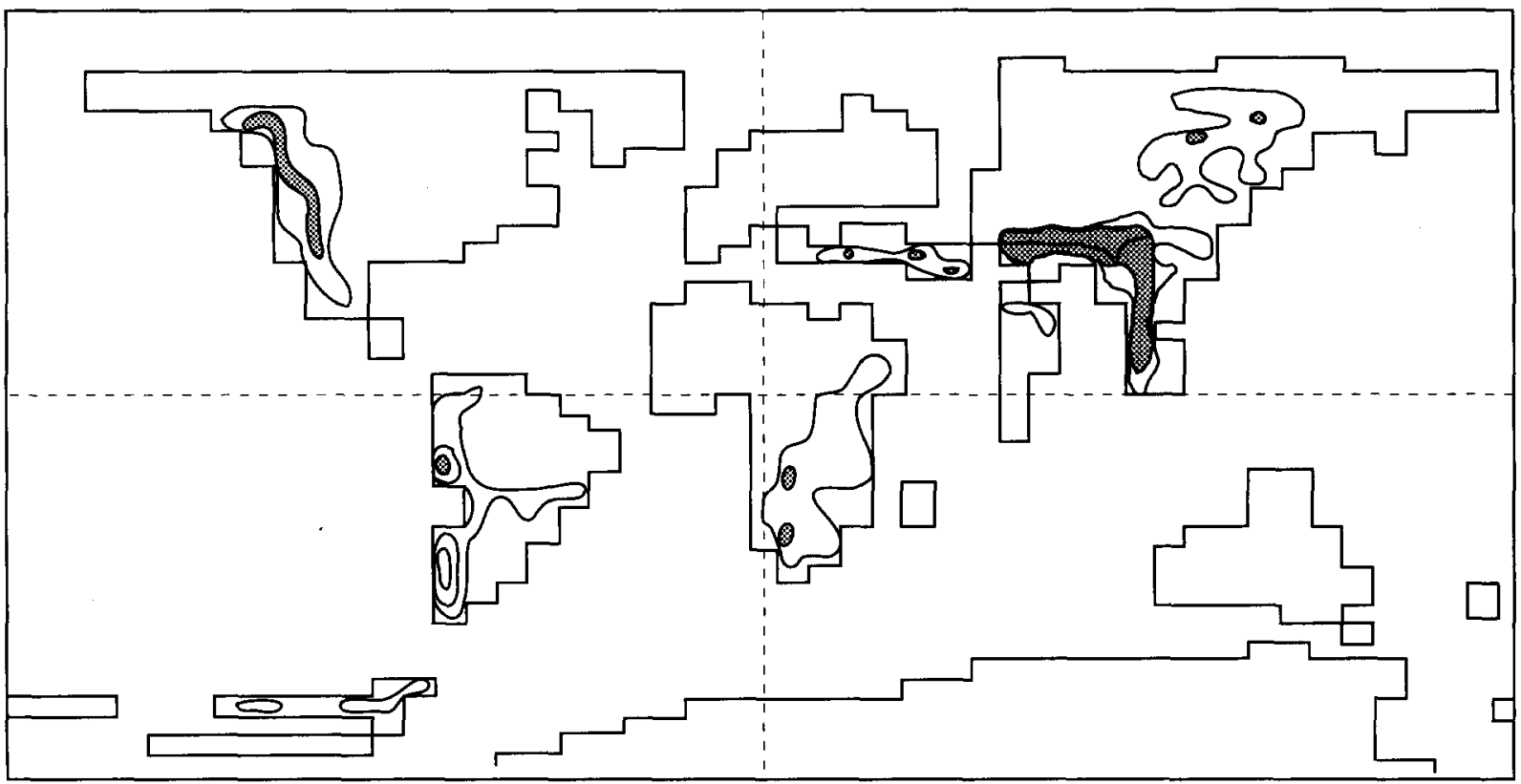

Fig. 1. Land-sea distribution and continental topography specified for climate model experiments, from Barron (1985). Contour interval $500 \mathrm{~m}$, elevations greater than $1 \mathrm{~km}$ are shaded.

approximately 40 Ma was specified (Fig. 1), taken from Barron (1985). This continental reconstruction is meant to be a representative approximation of Eocene conditions. Continental elevations (Fig. 1) were also specified based on Barron (1985). These values result in Eocene Rocky Mountains with a maximum elevation of $1 \mathrm{~km}$, and maximum elevations in the area of the Tibetan Plateau of nearly $3 \mathrm{~km}$. SST values at all points were defined by a temperature-latitude relationship, and ocean surface temperatures were held constant across each model latitude (explained in more detail below). Snow and sea ice components were fixed in the model.

\section{Climate model experiments}

Four climate model experiments were completed in this investigation, two January and two July scenarios. As reported above, all experiments contain the same geography and continental elevations, representing approximate Eocene conditions (Fig. 1). All cases incorporate the same continental albedo, an atmospheric $\mathrm{CO}_{2}$ content of $330 \mathrm{ppm}$, and the same solar constant value of $1370 \mathrm{~W} \mathrm{~m}^{2}$. The key and only difference between each pair of
January and July cases was the SST distribution incorporated within the model.

Two SST distributions were defined by latitudinal ocean surface temperature gradients which are shown in Fig. 2. The pole-to-equator surface temperature gradients were constrained to be symmetric about the equator. Ocean surface temperatures at each model latitude were assigned based on the temperature values in Fig. 2, and temperatures were constant across the model latitude. While restrictions of latitudinally constant and equatori-

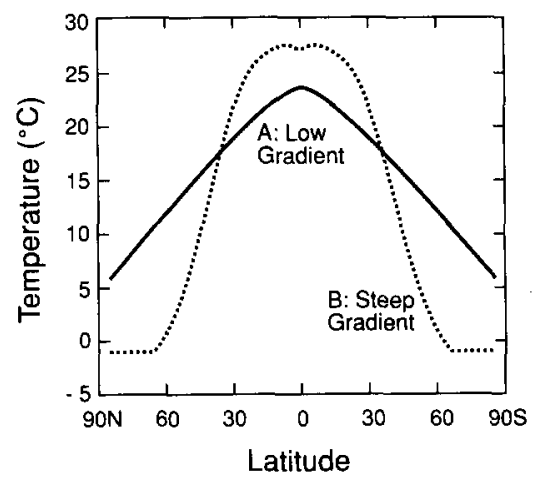

Fig. 2. Sea surface temperature gradients used to specify the ocean surface temperature distributions in the model cases. A. "Low gradient". B. "Steep gradient". 
ally symmetric temperature distributions are not completely realistic, the specifications were used to compensate for unknown temperature characteristics of ancient ocean surfaces. The SST distributions are used here to represent extreme endmember conditions of ocean surface temperature for the Eocene, and will be evaluated in terms of plausibility by comparison to paleoclimatic proxy data.

One meridional ocean surface temperature distribution is based upon early Eocene oxygen isotopic data from a variety of sources (e.g., Shackleton and Boersma, 1981; Oberhansli and Hsu, 1986; Boersma et al., 1987); the data were combined to produce a composite latitudetemperature relationship. Data were converted to SST values with the assumption that no significant ice existed during that time. The early Eocene was chosen because it is considered to have been the warmest interval of the Paleogene and therefore is an extreme temperature distribution to examine. The gradient produced from the isotopic data is reduced relative to the presently observed, global ocean surface temperature gradient and is referred to in this paper as the "low gradient" distribution. The "low gradient" has tropical surface temperatures that are $2-3^{\circ} \mathrm{C}$ lower than present values (Fig. 2). Polar surface temperatures have a minimum value of $6^{\circ} \mathrm{C}$ (Fig. 2), and no sea ice is specified.

The second distribution is based upon the modern, mean annual, global ocean surface temperature gradient computed from monthly ocean surface temperatures of Forderhase et al. (1980). This case had tropical temperatures of approximately $28^{\circ} \mathrm{C}$ and sea ice poleward of latitude $65^{\circ}$. Because this latitudinal distribution defines a more pronounced pole-to-equator gradient than in the first case, this gradient and the resulting SST distribution are referred to as "steep gradient" cases.

The model was run for January and July conditions (400 days for each case), with solar radiation and SST distributions fixed in each experiment. These experiments provide an estimate of the average, seasonally extreme climate simulated to occur in conjunction with each of the specified SST distributions. The idea was to produce two representative climate regimes for comparison to paleoclimatic evidence, with the hope that one regime would more closely match paleoclimatic characteristics reconstructed from geologic information than would the other. Close correlation between inferred paleoclimatic characteristics and one model case could therefore be taken as an indication that the associated SST gradient resembled conditions during the early Eocene.

January and July conditions were used to estimate the minimum and maximum continental surface temperatures, respectively, for comparison to proxy data interpretations. The mean values of temperature or precipitation for January and July at each model gridcell were used to approximate annual mean conditions for those variables. This is useful because mean annual temperature and precipitation are the most common quantities for which proxy paleoclimatic data exist. In a similar manner, the difference between January and July surface temperatures at each model gridcell was used to describe the annual temperature range for each model SST scenario, also for comparison to paleoclimatic interpretations.

\section{Paleoclimatic proxy data}

Proxy data providing quantitative details about Eocene climate were assembled in order to evaluate the model-generated climate states. There were two requirements for the data; first, that the evidence be of early Eocene age, and second, that the proxy information be quantitative in nature. Attempts to restrict the data to the early Eocene are not errorfree. In some cases the stratigraphic identification of age is ambiguous, potentially increasing the error in correlation between proxy climatic data and model results. The requirement of quantified information restricted estimates to quantities of minimum temperature, mean annual temperature, annual temperature range, and mean annual precipitation. Model results provide these same parameters.

The majority of estimates derived from proxy climate data were interpreted from floral assemblages of both macrofossils and palynomorphs or from fossil leaf physiognomic characteristics. Quantitative estimates were also interpreted from 
TABLE 1

Early Eocene temperature estimates

\begin{tabular}{|c|c|c|c|}
\hline Region & Temperature parameter* & Medium & Source \\
\hline Miss. embayment & MAT $26-30^{\circ} \mathrm{C}$ & flora & Wolfe and Poore (1982) \\
\hline N. America "midlatitude" & $\mathrm{ATR} \sim 7^{\circ} \mathrm{C}$ & flora & Wolfe and Poore (1982) \\
\hline Wind River Basin & $\begin{array}{l}\text { MAT } 19-23^{\circ} \mathrm{C} \\
\text { ATR } 15^{\circ} \mathrm{C} \\
\text { Min } T 15^{\circ} \mathrm{C}\end{array}$ & flora & MacGinitie (1974) \\
\hline Wind River Basin & $\begin{array}{l}\text { MAT }>13^{\circ} \mathrm{C} \\
\text { ATR } 22-28^{\circ} \mathrm{C}\end{array}$ & fiora & Leopold and MacGinitie (1972) \\
\hline Idaho & MAT $12.5^{\circ} \mathrm{C}$ & Salmon River flora & Axelrod (1966) \\
\hline Idaho & $\operatorname{MAT} 12^{\circ} \mathrm{C}$ & Thunder Mtn. flora & Axelrod (1966) \\
\hline North Dakota & $\begin{array}{l}\text { MAT } 15-18^{\circ} \mathrm{C} \\
\text { ATR } 10-16^{\circ} \mathrm{C} \\
\text { Min } T 6-13^{\circ} \mathrm{C}\end{array}$ & Golden Valley flora & Hickey (1977) \\
\hline NW North America & MAT $27-28^{\circ} \mathrm{C}$ & flora & Wolfe and Poore (1982) \\
\hline California & MAT $18^{\circ} \mathrm{C}$ & (Chalk Bluff) flora? & MacGinitie (1941) \\
\hline Baja California & MAT $20-25^{\circ} \mathrm{C}$ & paleosols & Peterson and Abbott (1979) \\
\hline Baja California & MAT $25^{\circ} \mathrm{C}$ & paleosols & Abbott et al. (1976) \\
\hline Washington & $\operatorname{MAT} 14^{\circ} \mathrm{C}$ & Republic flora (?) & Axelrod (1966) \\
\hline Green River Basin & $\operatorname{MAT} 18^{\circ} \mathrm{C}$ & varves, basin sizes & Bradley (1929) \\
\hline Alaska & Mat $11-18^{\circ} \mathrm{C}$ & palynomorphs & Dickinson et al. (1987) \\
\hline
\end{tabular}

*MAT = mean annual temperature, ATR = annual temperature range.

TABLE 2

Early Eocene precipitation estimates

\begin{tabular}{|c|c|c|c|}
\hline Region & $\begin{array}{l}\text { Precipitation rate } \\
(\mathrm{cm} / \mathrm{yr})\end{array}$ & Medium & Source \\
\hline Wind River Basin & $90-140$ & flora & MacGinitie (1974) \\
\hline Green River Basin & $76-109$ & $\begin{array}{l}\text { lake area/ } \\
\text { drainage calculation }\end{array}$ & Bradley (1929) \\
\hline North Dakota & $129-147$ & flora & Hickey (1977) \\
\hline Baja California & $>125-190$ & paleosols & Peterson and Abbott (1979) \\
\hline Baja California & $>127.6$ & paleosols & Abbott et al. (1976) \\
\hline California & $152-203$ & (Chalk Bluff) flora & MacGinitie (1941) \\
\hline Alaska & $80-200$ & palynomorphs & Dickinson et al. (1987) \\
\hline
\end{tabular}

faunal evidence, paleosols, and in one case, from calculations of lake basin areas and drainage systems. Tables 1 and 2 list temperature and precipitation estimates and the proxy climatic indicator sources. These estimates are derived from geologic evidence by several general methods. The limits in the interpreted paleoclimatic conditions are important to realize because this information is used to evaluate model results.

One method of interpreting paleoclimatic conditions is based on associating the ancient flora or fauna with extant forms (e.g., Colbert, 1964; Leopold and MacGinitie, 1972; MacGinitie, 1974; Estes and Hutchinson, 1980; Axelrod, 1984 ). The method requires identifying fossil organisms and relating them to living forms at the closest taxonomic levels. Observed climatic tolerances for the extant forms are extended to the fossil forms. This approach is most commonly applied and most robust when entire assemblages of organisms are considered in the paleoclimatic interpretations.

From the perspective of relating the paleocli- 
matic interpretations to model results, there are several potential problems with this method of interpretation. First, the factors controlling assemblage composition may be problematic. For example, the composition of a forest assemblage is not likely to be singly controlled by temperature extremes, mean annual temperature, or by precipitation regimes. Organisms are affected by a suite of factors which act collectively within the environment, and attempts to identify a single factor as responsible for the entire effect may be at worst, unrealistic, and at best, a narrow view of the (paleo)climate state. Second, inference of climatic factors from fossil biota generally requires some information, or more likely, assumptions, regarding the paleoenvironmental setting. Paleoclimatic and paleoecologic conclusions cannot be accurately made without some knowledge of the geography and environment of the original site (Fritz, 1980). Erroneous assumptions about environmental setting (for example, paleoelevations) could lead to incorrect climatic interpretations. Third, there are problems in relating climatic preferences and tolerances of fossil organisms to modern relatives (e.g., Colbert, 1964; Wolfe, 1978). Ecologic tolerances in related organisms may not remain constant over geologic time, and so this assumption could produce incorrect climatic interpretations. Another element of uncertainty relating to paleoclimatic interpretations via the above method is that interpretation of minimum temperatures for flora and fauna may be complicated by the possibility of a dormant state for organisms under conditions of high stress or by the possibility of animal migration (as a response to winter temperatures or high-latitude darkness) (Colbert, 1964; Axelrod, 1984; Parrish et al., 1987; Brouwers et al., 1987).

A second approach for interpreting quantitative paleoclimatic characteristics from fossils applies primarily to floral evidence. In this case the basis lies in correlation between physiognomic characteristics of plant structures and climatic elements of the ambient environment (see descriptions in Wolfe and Upchurch, 1987, Upchurch and Wolfe, 1987). Physiognomic characteristics such leaf margin structure and leaf area are interpreted as parameters such as moisture and light conditions
(Wolfe, 1985; Upchurch and Wolfe, 1987). For example, leaf size and percentage of leaves with entire margins generally increase with increasing climatic warmth (Frakes and Kemp, 1973; Wolfe, 1978, 1985). An advantage of this method is that interpretations are based on observed relationships between modern plant physiognomies and climate but are independent of taxonomic affinities and climatic tolerances of extant relatives (Wolfe, 1985). However, one potential problem with this method is the actual quantification of paleoclimate conditions. In physiognomic studies various plant types are related to observed mean annual temperature and mean annual precipitation (e.g., Wolfe, 1985); these quantified relationships may change through time, even by a small degree, which would affect the estimated temperature and precipitation values, and in turn affect comparison with modelpredicted quantities.

A third source for information about paleoclimates involves abiotic media. Conditions under which soil types or mineral deposits presently form are used to estimate past conditions of temperature and moisture for formation of these deposits. Bauxites and laterites are two media from which quantitative paleoclimate estimates have been made (Overstreet, 1964; Abbott et al., 1976; Peterson and Abbott, 1979). For example, Peterson and Abbott (1979) infer mean annual temperature of $20-25^{\circ} \mathrm{C}$ for southwestern California during the early Eocene on the basis of soil horizons formed at that time. However, climatic interpretations from these media are not without uncertainty. For example, Bird and Chivas (1989) and Bird et al. (1990) suggest that kaolinitic Tertiary regoliths of Australia may have formed in relatively cold conditions, contrary to the traditional interpretation of formation under tropical or subtropical climatic conditions.

Descriptions and interpretations of proxy paleoclimatic indicators were taken directly from literature and no secondary climate interpretations were made. Our comparison focuses on validating model results with paleoclimatic proxy data from North America. With regard to using the paleoclimatic interpretations in this study, comparisons between model results and paleoclimatic evidence may show variation arising from the above-cited 
limitations, as well as from the spatial and temporal limitations of the model.

\section{Comparison of model results to proxy climatic data}

\section{Summary of predicted and inferred Eocene climatic conditions}

Both January model cases indicate subfreezing surface temperatures for the interior of North America, with minimum surface temperatures rising towards continental margins. The low-gradient case produced a minimum temperature of $-10^{\circ} \mathrm{C}$ for the central interior of North America, and for the same region the steep-gradient case produced temperatures of $-20^{\circ} \mathrm{C}$. Both cases predict that the annual range of surface temperature variation for the Eocene would have been similar to the present annual range, with the low-gradient case predicting a maximum amplitude of approximately $52^{\circ} \mathrm{C}$ and the steep-gradient case predicting a maximum amplitude of approximately $62^{\circ} \mathrm{C}$. Both cases predict mean annual continental surface temperatures similar to presently observed values for much of North America during the Eocene. For the central interior of the continent, the lowgradient case predicts mean annual temperatures in the range of approximately $12-15^{\circ} \mathrm{C}$, and the steep-gradient case predicts approximately $5-10^{\circ} \mathrm{C}$ (compared to an observed, modern mean annual temperature in this area of approximately $10^{\circ} \mathrm{C}$ ). Both model cases predict a mean annual precipitation distribution with maximum precipitation occuring along the western and southern coastal regions of North America, similar to presently observed patterns. Differences between precipitation results for the two cases consist primarily of a greater amount of moisture being transported further into the continental interior of North America in the low-gradient case, and slightly different distribution patterns along the southeastern coast of North America.

The major difference between results from the two model cases is that conditions predicted from the "steep-gradient" case are generally more extreme for all variables. An interesting result is that model cases produce similar continental inte- rior surface temperatures despite the different SST distributions that were incorporated into the experiments. This suggests that surface temperatures for the continental interior have low sensitivity to variations in SST values (Sloan and Barron, 1990). This aspect of model behavior (or actual conditions) is a hindrance to the comparisons made here, because a substantial fraction of the data comes from continental interior sites.

In contrast to model results, for areas for which there are applicable data, proxy data interpretations indicate that minimum surface temperatures for North America were not less than $6^{\circ} \mathrm{C}$ (Hickey, 1977). Annual temperature ranges inferred from floristic assemblages are substantially reduced relative to present conditions, with estimates ranging from 7 to $28^{\circ} \mathrm{C}$ (Table 1). Mean annual temperatures in the range of $15-30^{\circ} \mathrm{C}$ are inferred from the proxy data (Table 1). Interpreted early Eocene precipitation patterns indicate a greater annual volume than presently occurs for areas of North America where data exist. Table 2 lists precipitation estimates for the North American data points.

\section{Criteria for comparison}

To relate model results to inferred paleoclimatic characteristics, criteria for "agreement" between the two types of information must be defined. Comparison of quantified information should be carried out through statistical evaluation of the goodness of fit between inferred and modelpredicted climatic variables, but the small number of proxy estimates restricts the statistical techniques that realistically can be applied. (For example, there are only three data points for inferred minimum surface temperature.) Standard deviations were calculated for the ensemble of interpreted values for each of the climatic parameters of minimum temperature, mean annual temperature, mean annual temperature range, and mean annual precipitation. Table 3 lists the individual values, the ensemble mean, and values for one and two standard deviations for each of these parameters. For each location, the margins of one and two standard deviations about each individual value of the proxy data were then used as two levels of 
TABLE 3

Explanation: For each climate parameter, values in column 1 correspond to proxy data interpretations listed in Tables 1 and 2. Columns 2 and 3 list corresponding model-produced quantities at the same locations as the proxy data sites. Columns 4 and 5 list differences between each model case and interpreted parameter value. At the bottom of each table the cumulative interpreted mean and standard deviations are listed, as well as the means for the "low gradient" and "steep gradient" cases.

\begin{tabular}{|c|c|c|c|c|}
\hline Interpreted & $\begin{array}{l}\text { Low } \\
\text { gradient }\end{array}$ & $\begin{array}{l}\text { Steep } \\
\text { gradient }\end{array}$ & $\begin{array}{l}\Delta \\
\text { Low gradient - inferred }\end{array}$ & $\begin{array}{l}\Delta \\
\text { Steep gradient }- \text { inferred }\end{array}$ \\
\hline \multicolumn{5}{|c|}{ Minimum temperature $\left({ }^{\circ} \mathrm{C}\right)$} \\
\hline 15 & -6 & -6 & 21 & 21 \\
\hline 6 & -10 & -11 & 16 & 17 \\
\hline 13 & -10 & -11 & 23 & 24 \\
\hline
\end{tabular}

Interpreted mean $=11.3 ; 1$ standard deviation $=3.9 ; 2$ standard deviations $=7.8$; "low gradient" mean $=8.7$; "steep gradient" mean $=9.3$.

\begin{tabular}{lllll}
\hline Interpreted & $\begin{array}{l}\text { Low } \\
\text { gradient }\end{array}$ & $\begin{array}{l}\text { Steep } \\
\text { gradient }\end{array}$ & $\begin{array}{l}\Delta \\
\text { Low gradient }- \text { inferred }\end{array}$ & $\begin{array}{l}\Delta \\
\text { Steep gradient - inferred }\end{array}$ \\
\hline \multicolumn{2}{l}{$\begin{array}{l}\text { Mean annual temperature range }\left({ }^{\circ} \mathrm{C}\right) \\
45\end{array}$} & 48 & 33 & 33 \\
15 & 48 & 48 & 20 & 20 \\
28 & 48 & 58 & 43 & 48 \\
10 & 53 & 58 & 37 & 42 \\
16 & 53 & 58 & \\
\hline
\end{tabular}

Interpreted mean $=17.2 ; 1$ standard deviation $=6.6 ; 2$ standard deviations $=13.2$; "low gradient" mean $=$ 50.5 ; "steep gradient" mean $=53.0$.

\begin{tabular}{lccll}
\hline Interpreted & $\begin{array}{l}\text { Low } \\
\text { gradient }\end{array}$ & $\begin{array}{l}\text { Steep } \\
\text { gradient }\end{array}$ & $\begin{array}{l}\Delta \\
\text { Low gradient - inferred }\end{array}$ & $\begin{array}{l}\Delta \\
\text { Steep gradient - inferred }\end{array}$ \\
\hline \multicolumn{2}{l}{ Mean annual temperature $\left({ }^{\circ} \mathrm{C}\right)$} & & & \\
$11-18$ & 10 & -8 & $1-8$ & $17-26$ \\
12.5 & 7 & -10 & 5.5 & 22.5 \\
$15-18$ & 8 & -10 & $7-10$ & $25-28$ \\
$26-30$ & 16 & 21 & $10-14$ & $5-9$ \\
$15-18$ & 16 & 16 & $1-2$ & 5 \\
$13-23$ & 17 & 18 & $4-6$ & 4 \\
12 & 16 & 16 & 4 & 1 \\
14 & 14 & 13 & 0 & 1 \\
18 & 16 & 17 & 2 & 5 \\
25 & 17 & 20 & 8 & 5 \\
\hline
\end{tabular}

Interpreted mean $=18.0 ; 1$ standard deviation $=5.3 ; 2$ standard deviations $=10.7$; "low gradient" mean $=$ 13.7 ; "steep gradient" mean $=9.3$.

\begin{tabular}{rccll}
\hline Interpreted & $\begin{array}{l}\text { Low } \\
\text { gradient }\end{array}$ & $\begin{array}{l}\text { Steep } \\
\text { gradient }\end{array}$ & $\begin{array}{l}\Delta \\
\text { Low gradient }- \text { inferred }\end{array}$ & $\begin{array}{l}\Delta \\
\text { Steep gradient - inferred }\end{array}$ \\
\hline $\begin{array}{l}\text { Mean annual temperature }\left({ }^{\circ} \mathrm{C}\right) \\
129-147\end{array}$ & 30 & 30 & $99-117$ & \\
$80-200$ & 80 & 40 & $0-120$ & $99-117$ \\
$127-152$ & 50 & 50 & $77-102$ & $70-160$ \\
$152-203$ & 100 & 100 & $52-103$ & $52-103$ \\
$125-190$ & 100 & 100 & $25-40$ & $25-90$ \\
$76-140$ & 45 & 45 & $31-95$ & $31-95$ \\
\hline
\end{tabular}

Interpreted mean $=143.4 ; 1$ standard deviation $=39.2 ; 2$ standard deviations $=78.2$; "low gradient" mean $=$ 75.8 ; "steep gradient" mean $=60.8$. 
acceptance ranges to define "agreement" between the inferred climate estimate and the estimates from each case of model-predicted values. Overall there were a greater number of values from the low gradient case than the steep gradient case which fell within the one and two-standard deviation ranges of the inferred climate values. However, the total percentage of acceptance was low for all climatic parameters, less than $50 \%$, even within a two standard deviation margin. If possible in future work, the criteria for agreement should be dictated by the nature of the climatic parameter under consideration (i.e., taking into account natural variability of the climatic process).

\section{Minimum surface temperature}

Quantified estimates of mean minimum surface temperatures from geological data are limited to two areas of North America, located in North Dakota and the Wind River Basin (Table 1). The sites, located in their Eocene positions, are shown in Fig. 3. The minimum temperatures produced from the January climate experiments for the "low gradient" and "steep gradient" cases also are shown in Fig. 3, with the sites of proxy data indicated on the maps. For the locations examined, both model cases produce minimum temperatures that are far lower than those indicated by the proxy climate data (Fig. 3). Minimum temperatures interpreted for the North Dakota site and the Wind River Basin site are $6-13^{\circ}$ and $15^{\circ} \mathrm{C}$, respectively. For the "low gradient" model case minimum temperatures of $-10^{\circ}$ and $-6^{\circ} \mathrm{C}$ are predicted for model gridcells containing the respective data sites. For the "steep gradient" model case the minimum temperature values for the same sites are $-11^{\circ}$ and $-7^{\circ} \mathrm{C}$. For all estimates there is no agreement between model results and interpreted values within either one or two standard deviation margins about the interpreted values (Table 3).

The discrepancy between paleontologicallybased estimates of minimum surface temperatures and model results is at least due in part to the unrealistically cold temperatures that may be produced by the model for some continental interior regions, as indicated in the study of present-day climatic conditions mentioned above from Pitcher et al. (1983) and discussed by Schneider et al. (1985). Overly cold temperatures could also be produced by incorrect continental elevations incorporated into the model (Barron and Washington, 1984). Differences between the reconstructed and model-predicted temperatures could also be due to the influence of regional climate upon the proxy climate systems which is beyond the scale of the CCM to simulate. Alternatively, the interpretations are in error. Whatever the cause, estimates of minimum temperature present a problem in a comprehensive paleoclimatic reconstruction.

The amount of variation between model results and proxy interpretations that may be due to regional climate variations can be estimated by examining presently observed lake conditions for influence of a "lake effect". In western North America during the Paleogene, warmer winter surface temperatures might have occurred around lakes or in sheltered basins. A temperature "lake effect" may have been generated by Lake Gosiute, an areally extensive lake which covered much of Wyoming during the Eocene. The Eocene lake system, now represented most completely by the Green River Formation, is estimated to have ranged in areal extent from $10,000 \mathrm{~km}^{2}$ to $36,000 \mathrm{~km}^{2}$ during the early and middle Eocene (Bradley, 1964; Baer, 1987). For an estimate of the effect of the presence of a large lake upon surrounding land surface temperatures, records of recent January and July surface temperatures for sites around Lake Michigan were examined (Weather of U.S. Cities, 1981). Records of 30-year surface temperature averages indicate that lakeshore locations can experience mean annual temperature ranges that are reduced by up to $5^{\circ} \mathrm{C}$ compared to locations of similar elevation that are $120 \mathrm{~km}$ from the lakeshore. Average January temperatures are up to $7^{\circ} \mathrm{C}$ warmer near the lake edge than at $120 \mathrm{~km}$ distance. This general effect is present around the entire lake margin.

Existence of a regional, moderating lake effect could explain some of the discrepancy between model results and geologic data interpretations, although the interpreted and predicted values would still not agree. We acknowledge that a lake effect realistically cannot be invoked at all data 

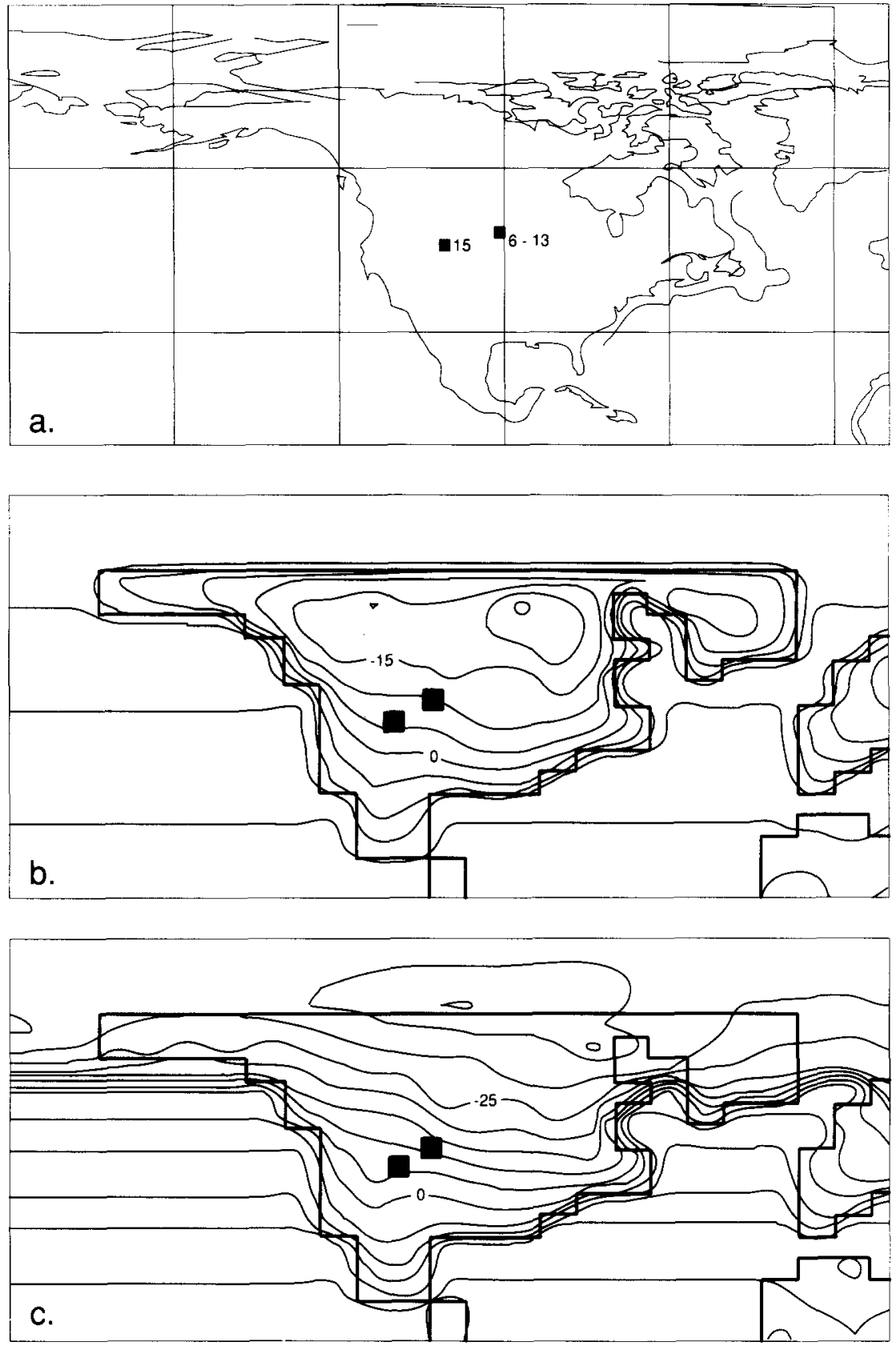

Fig. 3A. Minimum surface temperature estimates from proxy data, in ${ }^{\circ} \mathrm{C}$. B. January surface temperatures from "low gradient" case. C. From "steep gradient" case. For B and C, contour interval is $5^{\circ} \mathrm{C}$, proxy data sites of A are represented by squares.

sites where there is model result-data incompatibility. However, continental interior sites with and without lacustrine environments may provide data to test a hypothesis of lake-effect climatic moderation.

\section{Mean annual surface temperature}

There are more estimates of mean annual surface temperature than of minimum surface temperature for early Eocene North America (Table 1, Fig. 4). 

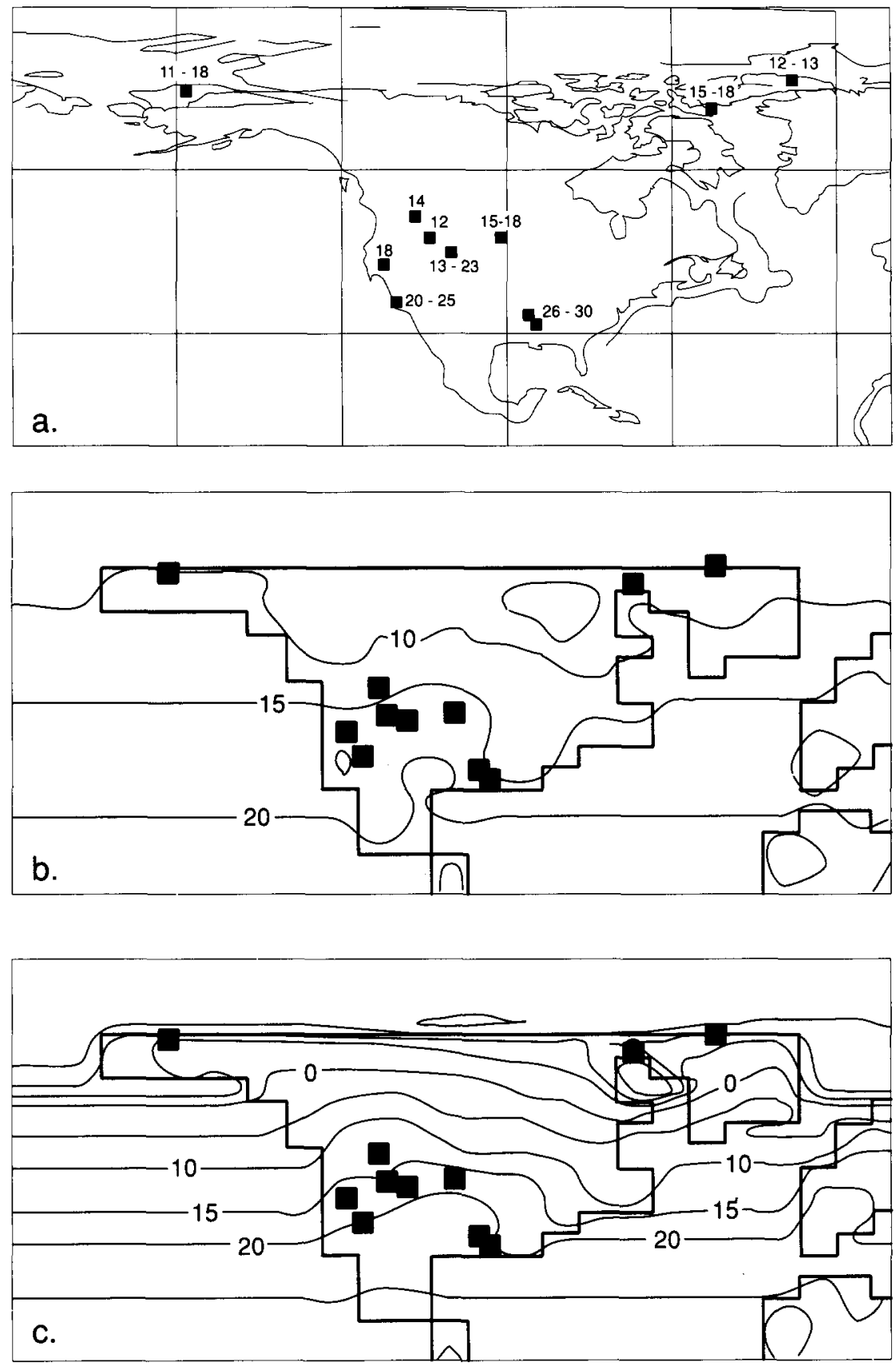

Fig. 4A. Mean annual surface temperature estimates from proxy data, in ${ }^{\circ} \mathrm{C}$. B. Mean annual surface temperature estimates from "low gradient" case. From C "steep gradient" case. For B and C, contour interval is $5^{\circ} \mathrm{C}$, squares indicate sites of $\mathrm{A}$.

From the model results for each SST gradient case, average January and average July conditions were combined to produce mean annual conditions for surface temperature and for precipitation. Figure 4 shows the averaged surface temperature distributions for the "low gradient" and "steep gradient" cases of each SST distribution, with the proxy data sites indicated. Unlike estimates of minimum temperature, model predictions of mean annual surface temperature are similar to the 
inferred values. Comparing model results and interpreted temperatures within a 2-standard deviation margin, the majority of sites show a match between the types of information - $100 \%$ for the "low gradient" case and 70\% agreement for the "steep gradient" case (Table 3). For North America, sites in the continental interior have the closest correlation between information types. In both model cases the $15^{\circ} \mathrm{C}$ isotherm is located very near the sites in the western interior (Fig. 4). The paleoclimatic evidence at these sites has been interpreted as indicating mean annual temperatures in the range of $13-23^{\circ} \mathrm{C}$, and both model cases produce favorable comparisons to the lower estimated temperature values.

Paleotemperature estimates from coastal areas show a less consistent relationship with the different cases of model results. At coastal sites, because interpreted mean annual temperatures were consistently warmer than any modelestimated mean annual temperature, the higher temperature value of the two model cases at each site corresponded more closely to the interpreted temperature value. In turn, coastal mean annual temperatures produced by the model were strongly influenced by adjacent SST values. The results are mean annual temperature estimates from high latitude coastal sites more closely resembling the "low gradient" results, while estimates from low latitude coastal sites were closer in value to results from the "steep gradient" model case (compare SST values for the two cases in Fig. 1). For example, mean annual temperatures in the range of $11-18^{\circ} \mathrm{C}$ are inferred from floral assemblages in Alaska and Ellesmere Island. These relatively warm temperature are closer in value to results from the "low gradient" case. The low gradient case incorporates warmer, high latitude ocean surface temperatures which warm high latitude coastal continental regions in those cases. In contrast, lower latitude, coastal paleoclimatic evidence from California and the Gulf Coast compare more favorably to the "steep-gradient" case, although Gulf Coast temperatures are well underestimated by both model cases relative to the interpreted temperatures (interpreted mean annual temperature of $26-30^{\circ} \mathrm{C}$, versus "low gradient" and "steep gradient" model-produced values of $16^{\circ} \mathrm{C}$ and $21^{\circ} \mathrm{C}$, respectively). The "steep gradient" case had warmer tropical SST values and as a result, warmer coastal regions. The inconsistent correlations between model-produced and interpreted temperatures are influenced to some degree by the unrealistic, latitudinally-constant specification of SST values.

\section{Mean annual surface temperature range}

Paleoclimatic interpretations of mean annual temperature ranges for Eocene North America are presented in Fig. 5. There are three sites, two in Wyoming and one in North Dakota (Table 1). From model results, an estimate of annual range of temperature was taken from the difference between the January and July surface temperature at each model grid point for each SST gradient. The results, shown in Fig. 5, do not provide a good basis for comparison with available data because values are similar in both cases. Both model cases produce temperature ranges far in excess of interpreted ranges. The "low gradient" case produces a slightly smaller annual temperature range for most areas in comparison to the "steep gradient" results, but model estimates of annual temperature amplitude in both cases exceed the interpretations from paleoclimatic indicators at all three sites by at least $20^{\circ} \mathrm{C}$. For example, an estimated mean annual surface temperature range of $15^{\circ} \mathrm{C}$ is interpreted from floral evidence recovered from the Wind River Basin, while model cases predict an annual temperature range of approximately $42-56^{\circ} \mathrm{C}$. The difference in values is in part an artifact of the modeled excessively cold minimum temperatures and the slightly higher maximum temperatures as discussed above, but minimum surface temperatures of $5-7^{\circ} \mathrm{C}$ in excess of observed values and maximum surface temperatures of $1-2^{\circ} \mathrm{C}$ in excess of observations would contribute a cumulative maximum of only $9^{\circ} \mathrm{C}$ to the annual range. This does not explain the total discrepancy. None of the sites have agreement at either 1 or 2 standard deviation levels between model results and inferred annual temperature ranges.

Regional climatic influences must be considered as a factor for reducing the annual surface temper- 

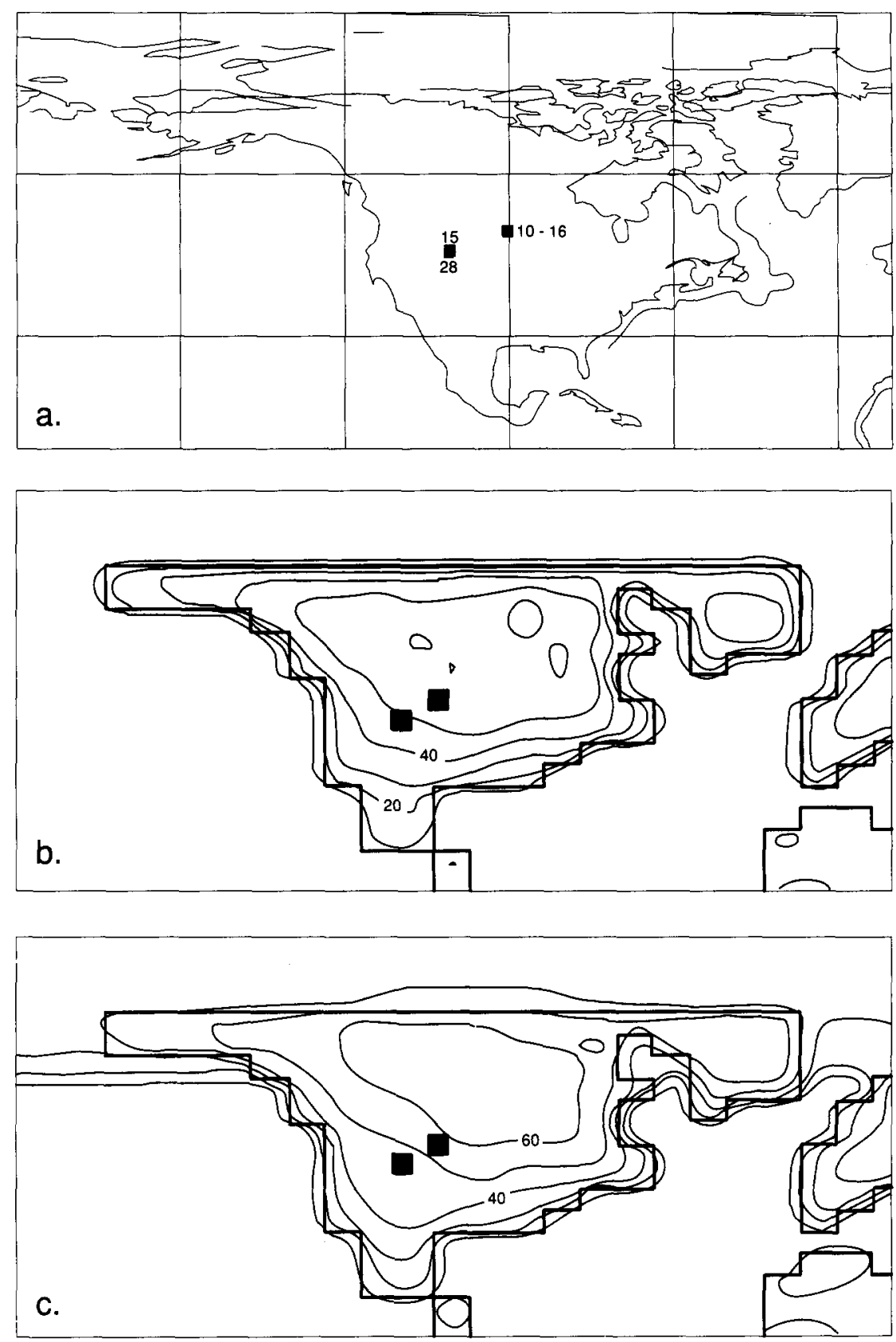

Fig. 5A. Mean annual surface temperature range estimates from proxy data, in ${ }^{\circ} \mathrm{C}$. B. Mean annual surface temperature range computed for "low gradient" case. C. "Steep gradient" case. For B and C, contour interval is $10^{\circ} \mathrm{C}$, squares indicate positions of proxy data sites.

ature range. As discussed above, a large lake could potentially reduce the seasonal cycle of surface temperature for regions adjacent to the lake, but based on observations this cannot account for more than a few degrees of reduction in temperature amplitude. Estimates of mean annual temperature range present a problem in this paleoclimatic analysis. 


\section{Mean annual precipitation}

Quantified estimates of annual precipitation during the early Eocene are presented in Fig. 6. There are several sites available for both coastal and interior environments. Mean annual precipitation for each model case was calculated in the manner outlined above for mean annual temperature, and
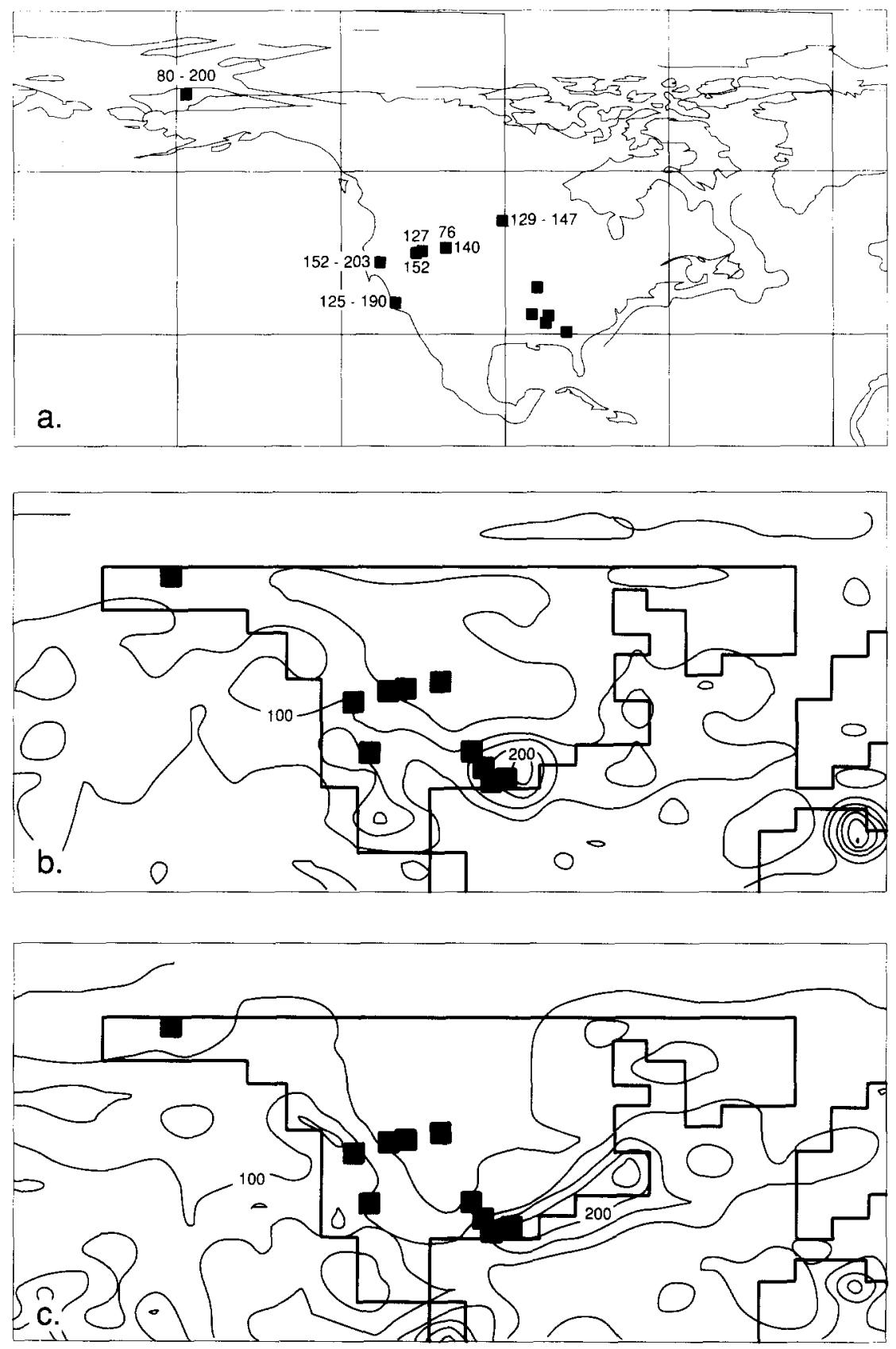

Fig. 6A. Mean annual precipitation estimates from proxy data $(\mathrm{cm} / \mathrm{yr})$. Asterisks without numbers represent bauxite deposits of early Eocene age, thought to form under conditions of high annual precipitation (Overstreet, 1964). B. Mean annual precipitation computed for "low gradient" case. C. "Steep gradient" case. For B and C, contour interval is $50 \mathrm{~cm} / \mathrm{yr}$, proxy data sites indicated by squares. 
these results are also shown in Fig. 6. In comparison to interpretations, both cases of model results exhibit the same approximate distributions of precipitation that are derived from the geologic evidence. Precipitation amounts produced by the "low gradient" SST case more closely match estimates of mean annual precipitation than do results from the "steep gradient" case at the 1 and 2 standard deviation levels, although not by much (Table 3). The most interior sites show greatest deviation between the inferred precipitation and the simulated "low gradient" result; annual precipitation from the Golden Valley Formation of North Dakota is estimated to have been at least $129 \mathrm{~cm} / \mathrm{yr}$ (Hickey, 1977) while the "low gradient" mean annual precipitation indicates less than $50 \mathrm{~cm} / \mathrm{yr}$ in that region. This discrepancy may be due to regional climatic control that is beyond the model to identify and simulate, and to limitations in model resolution (e.g., lack of mesoscale precipitation).

\section{Discussion}

In our attempt to relate model results to quantified paleoclimatic estimates we examined the discrepancies between conclusions from these two sources of information. Our examination of quantified paleoclimatic information provided some possible sources of the discrepancies, but provided no definite conclusions. As a preliminary study, however, several useful concepts and issues are apparent.

In the comparison of paleoclimatic estimates to climate model results for two SST cases, neither case produced results that consistently or satisfactorily matched all quantified temperature and precipitation parameter estimates for the early Eocene. Part of this problem is due to the fact that continental interior surface temperatures proved to be relatively insensitive to changes in specified SSTs, and so similar results were produced in the continental interior for both SST cases. In a relative sense, the "low-gradient" SST distribution produced climatic conditions that were more frequently considered to match the proxy climate data values at a level of two standard deviations, but not to a degree which would indi- cate that the specified reduced meridional surface temperature gradient may have existed during the early Eocene. The results do not rule out this possibility, nor do they strongly support it. However, in our opinion, a reduced gradient of some value may produce results most resembling early Eocene conditions of high latitude warmth and humidity.

In general, model results roughly approximate inferred mean annual temperatures, even for the continental interior. The potential model bias of too-low winter surface temperatures and too-high summer temperatures over regions of the continent could result in a mean annual temperature with a small cool bias since the possible error observed for winter temperatures was greater than error observed for summer temperatures. Differences between model results and proxy data at continental margin sites suggest that idealized parameterization of ocean surface temperature values may be responsible for mean annual temperature differences in coastal areas. With modification of the SST distribution to a somewhat more realistic character (e.g., effects of boundary currents upon SST values at ocean margins) it is likely that the "low gradient" case could produce continental climate results that even more closely resemble proxy paleoclimate estimates, especially at low latitude coastal sites.

Other physical factors may also be responsible for differences between model results and proxy interpretations. Large variations in model boundary conditions of continental elevation or of atmospheric $\mathrm{CO}_{2}$ content may produce significantly different model results. In the case of elevation, lower mountain heights may have permitted increased penetration of maritime air to the continental interior (e.g., Kutzbach et al., 1989). However, in a sensitivity study not included here, a model simulation identical to the "low gradient" case but with maximum North American elevations of $500 \mathrm{~m}$ did not produce continental interior surface temperature minima that were more than $5{ }^{\circ} \mathrm{C}$ warmer than the "low gradient" case. That result would diminish differences between model results and proxy data interpretations but would not erase them. The possibility remains that other descriptions of continental elevations may result 
in a climate whch resembles more closely that described by the proxy data interpretations.

Atmospheric $\mathrm{CO}_{2}$ concentrations greater than $330 \mathrm{ppm}$ may also produce a different climate (e.g., Barron and Washington, 1982; Washington and Meehl, 1984; Washington and Meehl, 1989), and one that may more closely resemble the early Eocene climate reconstructed from proxy data. Such a GCM investigation should be undertaken with a model version containing an ocean parameterization more complex than fixed SSTs, however. While an elevated $\mathrm{CO}_{2}$ concentration could produce a climate more similar to that reconstructed from proxy data, Crowley et al. (1989) have pointed out that this is not likely to significantly change the annual temperature range or seasonality of the resulting climate.

While this study did not completely explain the early Eocene climate record, it points out some considerations for future studies which relate model results and proxy climate data, or for studies of either type of information alone. First, the use of simple average climate produced by a climate model may not be realistic in terms of what is recorded by proxy records and should not, therefore, be the only state of model results to be related to proxy climate data. It might be more informative to include some estimate of variation about the mean climate state, which might be expected to be different for each climate parameter considered. Variation also might be more useful when expressed on a seasonal, decadal, or century scale for test comparisons. Similarly, associating the results from a single model grid cell to proxy data estimates may not be the best approach. Kutzbach and Guetter (1980) suggest using an area greater than the area of interest when relating point data to large-scale circulation systems; although their study was not considering GCM output specifically, their conclusion may be applicable here. The extent of model space to use for comparison to proxy data may vary with the climate variable considered, and possibly with the associated continental environment.

What is recorded by proxy climate indicators, and methods of extracting such information, should be examined more closely. Consideration must be given to whether or not the proxy elements are true representations of the associated climatic parameters. It has already been noted that organisms are affected by a suite of factors which act collectively within the environment, and attempts to identify a single factor as responsible for the existence of given biota would be inaccurate. Definite, unambiguous, and quantitative climatic estimates are ideally what are needed for optimum correlation with climate model results. Lacking those, we must construct better ways to deal with the non-ideal climatic estimates that are available, and strive for more complete continental data bases and additional, independent methods of estimating climatic conditions.

The issue of continentality, in terms of seasonal temperature amplitude for the continents, remains a significant problem in paleoclimatic reconstructions. Based on arguments of seasonality and continentality (e.g., Schneider et al., 1985; Crowley et al., 1986, 1987; Kutzbach and Gallimore, 1989; Sloan and Barron, 1990), the annual temperature range for the continental interior of North America should be similar for the Eocene and today, assuming no variation in external forcing factors. This is, in fact, what the model results indicate. Yet the proxy data indicate a much smaller range of annual temperature than presently observed. This issue remains unresolved. One problem is that there are only three quantified paleoclimatic estimates of mean annual temperature range available for this study, which makes a comparison with model results difficult. Another problem is that proxy estimates of mean annual temperature range may be too ambiguous; specifically, mean annual temperature range may not leave a clear signal in proxy data.

Regional climatic influence is an important factor that is presently beyond the capabilities of the GCMs to explicitly consider. Potentially, regional climatic forcing is a major influence upon the proxy climate record. Methods to express regional climatic influence should be considered in future modeling studies and studies that combine model information with data inferences.

\section{Conclusions}

We document an attempt to relate climate model results to quantified paleoclimatic interpretations 
from the geologic record. While the results were not conclusive for the Eocene scenario tested, comparison of results and data suggest that a reduced meridional SST gradient of some type, with warm high latitude SSTs, may have existed during the early Eocene. The comparison between model results and geologic data interpretations produced encouraging results for future combined model-data studies, especially for mean annual temperature and mean annual precipitation. Minimum temperature and annual temperature range estimates remain a problem in paleoclimatic reconstructions.

For many intervals of geologic time the record of climate-related events is being clarified, especially with the integration of marine and terrestrial information. Hopefully such clarification will produce better resolved climatic signals to be used for paleoclimatic reconstructions. In addition, climate models are being modified to incorporate finer spatial resolutions. With increasing volumes of data and increasing model spatial resolution there will be a greater use for quantitative comparisons of model results and paleoclimate proxy data. Research in defining the range of variation in results that should be compared to proxy data would be very useful in paleoclimate studies; "average" climate may not be a realistic state for comparison to recorded climatic signals. It is likewise necessary to gain a better understanding of what is recorded by the floral, faunal, and abiotic systems; this will be of use for many aspects of paleoclimate research. Comparisons such as this, of model results and climatically-interpreted geologic evidence, encourages interdisciplinary analyses of paleoclimates. An interdisciplinary view may be the best way to approach issues of paleoclimatic reconstruction.

\section{Acknowledgements}

We thank Catherine Badgley, Gregg Bluth, Phil Gingerich, and Bruce Wilkinson for insightful discussions regarding preliminary versions of this work. We also thank the reviewers, Tom Crowley and Bill Ruddiman, for helpful comments. This research was carried out while under funding from NSF (ATM-8804084, to EJB), and much of the manuscript was written while LCS was funded by NASA grant NAGW-176 to J.C.G. Walker at Michigan.

\section{References}

Abbott, P.L., Minch, J.A. and Peterson, G.L., 1976. PreEocene paleosol south of Tijuana, Baja California, Mexico. J. Sediment. Petrol., 46: 355-361.

Adams, C.G., Lee, D.E. and Rosen, B.R., 1990. Conflicting isotopic and biotic evidence for tropical sea surface temperatures during the Tertiary. Palaeogeogr., Palaeoclimatol., Palaeoecol., 77: 289-313.

Axelrod, D.I., 1966. The Eocene Copper Basin Flora of Northeastern Nevada. Univ. Calif. Publ. Geol. Sci., 59, 83 pp.

Axelrod, D.I., 1984. An interpretation of Cretaceous and Tertiary biota in polar regions. Palaeogeogr., Palaeoclimatol., Palaeoecol., 45: 105-147.

Baer, J.L., 1987. Green River Formation (Eocene), central Utah: A classic example of fluvial-lacustrine environments. In: S.S. Bues (Editor), Centennial Field Guide: Rocky Mountain Sect. Geol. Soc. Am., 2. Geol. Soc. Am., Boulder, CO, pp. 247-250.

Barron, E.J., 1985. Explanations of the Tertiary global cooling trend. Palaeogeogr., Palaeoclimatol., Palaeoecol., 50: 45-61.

Barron, E.J., 1987. Eocene equator-to-pole surface ocean temperatures: A significant climate problem? Paleoceanography, 2: 729-739.

Barron, E.J. and Washington, W.M., 1984. The role of geographic variables in explaining paleoclimates: Results from Cretaceous climate model sensitivity studies. Palaeogeogr., Palaeoclimatol., Palaeoecol., 40: 1267-1279.

Barron, E.J. and Washington, W.M., 1982. The atmospheric circulation during warm geologic periods: Is the equator-topole surface temperature gradient the controlling factor? Geology, 10: 633-636.

Bird, M.I. and Chivas, A.R., 1989. Stable-isotope geochronology of the Australian regolith. Geochim. Cosmochim. Acta, 53: 3239-3256.

Bird, M.I., Fyfe, B., Chivas, A. and Longstaffe, F., 1990. Deep weathering at extra-tropical latitudes: A response to increased atmospheric $\mathrm{CO}_{2}$. In: A.F. Bouwman (Editor), Soils and the Greenhouse Effect. Wiley, London, pp. 383-389.

Boersma, A., Premoli Silva, I. and Shackleton, N.J., 1987, Atlantic Eocene planktonic foraminiferal paleohydrographic indicators and stable isotope paleoceanography. Paleoceanography, 2: 287-331.

Bradley, W.H., 1929. The varves and climate of the Green River Epoch. U.S. Geol. Surv. Prof. Pap., 158-E: 87-110.

Bradley, W.H., 1964. Geology of Green River Formation and associated Eocene rocks in southwestern Wyoming and adjacent parts of Colorado and Utah. U.S. Geol. Surv. Prof. Pap., 496-A: 1-86.

Brouwers, E.M., Clemens, W.A., Spicer, R.A., Ager, T.A., Carter, L.D. and Sliter, W.V., 1987. Dinosaurs on the North Slope, Alaska: High latitude, latest Cretaceous environments. Science, 237: 1608-1610.

Colbert, E.H., 1964. Climatic zonation and terrestrial faunas. 
In: A.E.M. Nairn (Editor), Problems in Palaeoclimatology. Wiley, London, pp. 617-637.

Crowley, T.J., Hyde, W.T. and Short, D.A., 1989. Seasonal cycle variations on the supercontinent of Pangaea. Geology, 17: 457-460.

Crowley, T.J., Short, D.A., Mengel, J.G. and North, G.R., 1986. Role of seasonality in the evolution of climate during the last 100 million years. Science, 231: 579-584.

Crowley, T.J., Mengel, J.G. and Short, D.A., 1987. Gondwanaland's seasonal cycle. Nature, 329: 803-807.

Dickinson, K.A., Cunningham, K.A. and Ager, T.A., 1987. Geology and origin of the Death Valley Uranium deposit, Seward Peninsula, Alaska. Econ. Geol., 82: 1558-1574.

Estes, R. and Hutchison, J.H., 1980. Eocene lower vertebrates from Ellesmere Island, Canadian Arctic Archipelago. Palaeogeogr., Palaeoclimatol., Palaeoecol., 30: 325-347.

Forderhase, K.M., Washington, W.M., Chervin, R.M., Ramanathan, V., Williamson, D.L. and Knight, D.J., 1980. Lower boundary conditions for the NCAR global circulation model: Ocean surface temperatures, sea ice, snow cover, continental surface albedos and surface emissivity, subsurface continental temperatures, and mountain heights. NCAR Tech. Note TN-157+STR, Boulder, CO, 58 pp.

Frakes, L.A. and Kemp, E.M., 1973. Paleogene continental positions and evolution of climate. In: D.H.Tarling and S.K. Runcorn (Editors), Implications of Continental Drift to the Earth Sciences. Academic Press, New York, NY, pp. $541-559$.

Fritz, W.J., 1980. Reinterpretation of the depositional environment of the Yellowstone "fossil forests". Geology, 8: 309-313.

Gale Research Corp.,1900. Weather of U.S. Cities, vol. 1, 2. Detroit, MI, $1189 \mathrm{pp}$.

Hickey, L.J., 1977. Stratigraphy and paleobotany of the Golden Valley Formation (early Tertiary) of western North Dakota. Geol. Soc. Am. Mem., 150, 183 pp.

Kutzbach, J.E. and Guetter, P.J., 1980. On the design of paleoenvironmental data networks for estimating large-scale patterns of climate. Quat. Res., 14: 169-187.

Kutzbach, J.E., and Wright Jr., H.E., 1985. Simulation of the climate of 18,000 years BP: Results for the North American/ North Atlantic/European sector and comparison with the geologic record of North America. Q. Sci. Rev., 4: 147-187.

Kutzbach, J.E. and Gallimore, R.G., 1989. Pangaean climates: Megamonsoons of the Megacontinent. J. Geophys. Res., 94: 3341-3357.

Kutzbach, J.E., Guetter, P.J., Ruddiman, W.F. and Prell, W.L., 1989. Sensitivity of climate to Late Cenozoic uplift in Southern Asia and the American West: Numerical experiments. J. Geophys. Res., 94: 18,393-18,407.

Leopold, E.B. and MacGinitie, H.D., 1972. Development and affinities of Tertiary floras in the Rocky Mountains. In: A. Graham (Editor), Floristics and Paleofloristics of Asia and Eastern North America. Elsevier, Amsterdam, pp. 147-200.

MacGinitie, H.D., 1941. A middle Eocene flora from the central Sierra Nevada. Carnegie Inst. Washington Publ., 534, $94 \mathrm{pp}$.

MacGinitie, H.D., 1974. An early middle Eocene flora from the Yellowstone Absaroka volcanic province, northwestern
Wind River Basin, Wyoming. Calif. Univ. Publ. Geol. Sci., 108: 1-103.

Manabe, S. and Broccoli, A.J., 1985. The influence of continental ice sheets on the climate of an ice age. J. Geophys. Res., 90: $2167-2190$.

Manabe, S. and Broccoli, A.J., 1990. Mountains and arid climates of middle latitudes. Science, 247: 192-195.

Manabe, S. and Terpstra, T.B., 1974. The effects of mountains on the general circulation of the atmosphere as identified by numerical experiments. J. Atmos. Sci., 31: 1-42.

Matthews, R.K. and Poore, R.Z., 1980. The Tertiary del ${ }^{18} \mathrm{O}$ record: An alternative view concerning glacio-eustatic sea level fluctuations. Geology, 8: 501-504.

Oberhansli, H. and Hsu, K.G., 1986. Paleocene-Eocene paleoceanography. In: K.J. Hsu (Editor), Mesozoic and Cenozoic Oceans (Geodyn. Ser., 15). Am. Geophys. Union, Washington, DC, pp. 85-100.

Overstreet, E.F., 1964. Geology of the southeastern Bauxite deposits. U.S. Geol. Surv. Bull., 1199-A: A1-A19

Parrish, J.M., Parrish, J.T., Hutchison, J.H. and Spicer, R.A., 1987. Late Cretaceous vertebrate fossils from the North Slope of Alaska and implications for dinosaur ecology. Palaios, 2: 377-389.

Peterson, G.L. and Abbott, P.L., 1979. Mid-Eocene climatic change, southwestern California and northwestern Baja California. Palaeogeogr., Palaeoclimatol., Palaeoecol., 26: 73-87.

Pitcher, E.J., Malone, R.C., Ramanathan, V. Blackmon, M.L., Puri, K. and Bourke, W., 1983. January and July simulations with a spectral general circulation model. J. Atmos. Sci., 40: 580-604.

Prentice, M.L. and Matthews, R.K., 1988. Cenozoic ice-volume history: Development of a composite oxygen isotope record. Geology, 16: 963-966.

Ramanathan, V., Pitcher, E.J., Malone, R.C. and Blackmon, M.L, 1983. The response of a spectral general circulation model to refinements in radiative processes. J. Atmos. Sci., 40: $605-630$.

Rea, D.K., Zachos, J.C., Owen, R.M. and Gingerich, P.D., 1990. Global change at the Paleocene-Eocene boundary: climatic and evolutionary consequences of tectonic events. Palaeogeogr., Palaeoclimatol., Palaeoecol, 79: 117-128.

Rind, D., 1987. Components of the Ice Age circulation. J. Geophys. Res., 92: 4241-4281.

Ruddiman, W.F. and Kutzbach, J.E., 1989. Forcing of Late Cenozoic Northern Hemisphere climate by plateau uplift in Southern Asia and the American West. J. Geophys. Res., 94: 18,409-18,427.

Ruddiman, W.F., Prell, W.L. and Raymo, M.E., 1989. Late Cenozoic uplift in Southern Asia and the American West: Rationale for general circulation modeling experiments. J. Geophys. Res., 94: 18,379-18,391.

Schneider, S.H., Thompson, S.L. and Barron, E.J., 1985. MidCretaceous, continental surface temperatures: Are high $\mathrm{CO}_{2}$ concentrations needed to simulate above freezing winter conditions. In: E.T. Sundquist and W.S. Broecker (Editors), The Carbon Cycle and Atmospheric CO2: Natural Variations Archean to Present (Geophys. Monogr., 32). Am. Geophys. Union, Washington, DC, pp. 554-560.

Shackleton, N.J. and Boersma, A., 1981. The climate of the Eocene ocean. Geol. Soc. Lond. J., 138: 153-157. 
Shinn, R.A. and Barron, E.J., 1989, Climate sensitivity to continental ice sheet size and configuration. J. Climate, 2: 1517-1537.

Sloan, L. C., 1990. Determination of critical factors in the simulation of Eocene global climate, with special reference to North America. Thesis. Pennsylvania State Univ., 282 pp.

Sloan, L.C. and Barron, E.J., 1990. "Equable" climates in Earth history? Geology, 18: 498-492.

Sloan, L.C. and Barron, E.J., 1991. Reply to comment on "Equable" climates in Earth history? Geology, 19: 540-541.

Upchurch, G.R. and Wolfe, J.A., 1987. Mid-Cretaceous to Early Tertiary vegetation and climate: Evidence from fossil leaves and woods. In: E.M. Friis, W.G. Chaloner and P.R. Crane (Editors), The Origin of Angiosperms and their Biological Consequences. Cambridge Univ. Press, Cambridge, pp. 75-105.

Washington, W.M. and Meehl, G.A., 1984. Seasonal cycle experiments on the climate sensitivity due to a doubling of $\mathrm{CO}_{2}$ with an atmospheric general circulation model coupled to a simple mixed-layer ocean model. J. Geophys. Res., 89(D): 9475-9950.

Washington, W.M. and Meehl, G.A., 1989. Climate sensitivity due to increased $\mathrm{CO}_{2}$ : experiments with a coupled atmosphere and ocean general circulation model. Climate Dyn., 4: $1-38$.

Washington, W.M. and Williamson, D.L., 1977. A description of the NCAR global circulation models. In: J. Chang (Editor), Methods in Computational Physics (General Circulation Models of the Atmosphere, 17). Academic Press, New York, NY, pp. 111-172.

Wei, W., and Wise Jr., S.E., 1990. Biogeographic gradients of middle Eocene-Oligocene calcareous nannoplankton in the South Atlantic Ocean. Palaeogeogr., Palaeoclimatol, Palaeoecol., 79: 26-91.

Wing, S.J., 1991. Comment on "Equable" climates in Earth history? Geology, 19: 539-540.

Wolfe, J.A., 1989. North American Eocene vegetation and its climatic implications. Trans. Am. Geophys. Union (EOS), 70: 375 .

Wolfe, J.A., 1978. A paleobotanical interpretation of Tertiary climates in the Northern Hemisphere. Am. Sci., 66: 694-703.

Wolfe, J.A., 1985. Distributions of major vegetational types during the Tertiary. In: E.T. Sundquist and W.S. Broecker (Editors), The Carbon Cycle and Atmospheric $\mathrm{CO}_{2}$ : Natural Variations Archean to Present (Geophys. Monogr., 32). Am. Geophys. Union, Washington, DC, pp. 357-376.

Wolfe, J.A. and Poore, R.Z., 1982. Tertiary marine and nonmarine climatic trends. In: Climate in Earth History (Natl. Res. Counc. Stud. Geophys.). Natl. Acad. Press, Washington, DC, pp. 154-158.

Wolfe, J.A. and Upchurch, G.R., 1987. North American nonmarine climates and vegetation during the Late Cretaceous. Palaeogeogr., Palaeoclimatol., Palaeoecol., 61: 33-77. 